Andrea Rodríguez Quiroga de Pereira, Laura Borensztein, Valeria Corbella \& Juan Carlos Marengo (2018) The Lara case: A group analysis of initial psychoanalytic interviews using systematic clinical observation and empirical tools, The International Journal of Psychoanalysis, 99:6, 13271352, DOI: $10.1080 / 00207578.2018 .1533374$

\title{
The Lara case: A group analysis of initial psychoanalytic interviews using systematic clinical observation and empirical tools
}

Andrea Rodríguez Quiroga de Pereiraa,d,f, Laura Borensztein b,d,f, Valeria Corbella $b, d, e, f$ and Juan Carlos Marengo c, d,f

apontificia Universidad Católica Argentina (UCA), Universidad del Salvador (USAL), Member adherente of the Psychoanalytic Association of Buenos Aires. Director of the IUSAM Department of Research

bMember adherente of the Psychoanalytic Association of Buenos Aires. Secretary of the IUSAM Department of Research

CUniversidad Favaloro, INECO - Instituto de Neurología Cognitiva, Egresado de la especialización en Psicoanálisis del Instituto Universitario de Salud Mental, Buenos Aires Psychoanalytic Association.

dlnstitute of Mental Health (Instituto Universitario de SaludMental, IUSAM).;

e Pontificia Universidad Católica Argentina (UCA), Universidad del Salvador (USAL)

$f$ Member of the IUSAM Psychodynamic Clinical Research Team

CONTACT Andrea Rodríguez Quiroga de Pereira amrqpereira@gmail.com Member of the Psychoanalytic Associ- ation of Buenos Aires. Director of the IUSAM Department of Research. Institute of Mental Health (Instituto Universitario de Salud Mental, IUSAM).

\section{Abstract:}

With the objective of analysing the usefulness of empirical criteria for observing psychoanalytic cases, this article describes an experience of systematic clinical observation carried out by the Psychodynamic Clinical Research Team at the Psychoanalytic Association of Buenos Aires' University Institute of Mental Health (Instituto Universitario de Salud Mental, IUSAM). A group of four psychoanalytic therapists, including the treating therapist, systematically analysed the first four interviews in the psychoanalytic treatment of a 32-year-old female patient, which was discontinued six months after it started. We used the combined frameworks of the Multilevel Observation and Three- Level Model to systematise the information. We also used a computer-assisted text- analysis system-the Discourse Attribute Analysis Program (DAAP) to measure Referential Activity. The ShedlerWesten Assesment Procedure (SWAP) was included as a diagnostic tool. We describe the application of these resources to our analysis of the four interviews, including examples of the clinical material. We discuss both the hypotheses developed by our clinical observation group and the usefulness of group exchange for understanding the therapeutic process in general. Finally, we discuss 
the implications of this type of systematic case study for clinical practice, training, and research in psychoanalysis.

Keywords: scientific research; psychoanalysis; empirical research; clinical case; training

This article describes an experience of systematic clinical observation, analysing the first four meetings of a psychoanalytic treatment that was discontinued six months after it started. The selected material corresponds to the treatment of a patient called Lara. The case was studied after it had been discontinued.

The clinical material was studied using the modality of group clinical observation in addition to empirical tools. It was hoped that this would maximise our understanding of the case. The experience made it possible to identify very early on the relevant aspects of the material, which, had they been identified sooner, would probably have been of use for the therapist, the patient, and the treatment, including potential predictors of dropout that were present in the way in which the transference-countertransference relationship developed in the analytic dyad.

The following observation merits emphasis: it does not appear to be simple for clini- cians as individuals to implement the contributions made by advances in psychodynamic research. The debate between Wallerstein (2005a) and Green (2005), which shows the dis- parity of criteria among psychoanalysts with respect to the production of knowledge- hermeneutics or positivism-probably explains the obstacle to some extent. This conflict is evident in the different theories, beliefs, and practices that prevail in each psy- choanalytic association, with the resulting consequences for how cases are conceptualised and how treatment is carried out. Group work thus takes on a central role in enabling clin- icians to take advantage of and benefit from research developments by offering an environment that fosters debate and discussion of the different theoretical frameworks to which they belong.

Westen (cited in Luyten, Blatt, and Corveleyn 2006) suggests that many psychoanalysts in different parts of the world are situated somewhere between these two cultures. These authors consider that analysts should implement bridging actions between clinic and research. From our perspective, this requires training that is not always easily obtained. Evidence of this difficulty lies in the scant incorporation of scientific articles in analyst train- ing programmes.

The experience described in this article attempts to integrate the two approaches-as suggested, for example, both by the OPD-2 Task Force (OPD Task Force 2008) and by Lan- celle (1997) -as our research team considers these cultures to be two poles on a conti- nuum and believes in the importance of triangulating these perspectives for clinical practice, training, and research in psychoanalysis.

To justify the criteria used, this article explores three questions: (1) Why analyse the first interviews of a psychoanalytic treatment? (2) Why analyse clinical material as a group? What does this contribute? (3) Why include empirical tools in studying the material?

\section{Why analyse the first interviews of a psychoanalytic treatment?}

The initial interviews of a treatment are often thought to allow therapists to make infer- ences that enable them to make early decisions, carry out specific interventions, and ident- ify possible predictors of the course of the treatment.

To be more precise, the elements that come out in the first interviews are, in general terms: diagnostic criteria, degree of analysability, prognosis, indications, and 
therapeutic strategies (Freud 1913; Liberman 1972; Kernberg 2006; PDM Task Force 2006; OPD Task

Force 2008).

Berenstein and Puget (1997) discuss aspects related to psychoanalytic technique, emphasising that from the very first interview the analyst has the opportunity to transmit something previously unknown to the patient, some useful and relevant knowledge, that can demonstrate the power of the unconscious.

Etchegoyen (1991) suggests that, following Pichon-Rivière (1971), most authors from the River Plate region of South America understand the analytic situation as a field of observation and interaction. The notion of field, coined by Baranger and Baranger (2008), sees the analytic pair as connected in a complementary manner, and neither of the two can be understood without the other. For Bleger (1971), this field is configured during the first interviews.

Liberman (1972) introduced indicators for the first interviews that make it possible to consider the compatibility of the analytic pair prospectively and allow the analyst to ident- ify the essential features of the person who will probably become his or her patient. This author proposes that, for diagnosis and prognosis, at least two interviews are necessary in order to "study both individually and comparatively what happens in the two interviews as well as the inferences about their development both during and between the interviews" (Liberman 1972, 466).

Several years earlier, Bergin (1963) considered the negative outcomes of psychother- apy. Following this line of research, Stein (1972, cited in Kächele and Schachter 2014) made a list of factors that can have a negative impact on the outcomes of psychotherapy, including diagnoses, external conditions, constitutional factors, the type of changes that occur in treatment, and, finally, transference and countertransference.

The first of these, diagnosis, is often considered by psychoanalysts to be an element in a general psychopathology classification scheme or merely a matter of nomenclature, calling its usefulness into question. The issue has been addressed from several perspec- tives. Authors such as Persano (2005; Persano, Ventura, and Weisbrot 2011), McWilliams (2011), and Bernardi (2010) propose that each patient's subjectivity and the characteristics he or she may have in common with other patients are not exclusive, but complementary. In line with the importance of the diagnosis in the first interviews, Skodol, Buckley, and Charles (1983, cited in Kächele and Schachter 2014) monitored patients in treatment classified by diagnosis and report that certain diagnoses are associated with higher rates of treatment failure and dropout.

Kächele and Schachter (2014) and Sandell (2012, cited in Kächele and Schachter 2014) suggest that some non-psychoanalytic psychotherapies for borderline patients that have rigorously engaged with the diagnostic process have improved their rates of efficacy. Kächele and Schachter (2014) closely examine the errors that can occur both in psycho- analytic psychotherapy and in psychoanalysis and report that analysts do not pay much attention to investigating possible errors in the diagnostic process that could have an impact on patient dropout.

Bernardi (2014a, 2014b; Bernardi et al. 2016) proposes implementing psychodynamic case formulation during the first interviews as a way to systematise the clinical data, including what is happening to the patient (diagnosis), why it is happening (etiopathogen- esis), the decision about the therapeutic indication, as well as an evaluation of progress, explaining the clinician's theoretical and technical opinion in each section. This model also makes it possible to evaluate prognostic inference. Juan et al. (2009) consider it rel- evant to take into account how prognostic judgement can be in line with each psy- chotherapist's own interventions, as long as these are consistent with the general treatment proposal. 
This proposal opens up a dialogue with psychotherapy in general, as case formulation is used across different theoretical approaches. At the same time, though, it brings us to the controversy about diagnoses in the initial interviews in psychoanalysis and about new interview modalities.

New interview modalities, different from open-ended interviews, are currently being recommended. Some examples that advance the potential for systematising cases include the Operationalized psychodynamic diagnosis (OPD-2) multiaxial and multimodal interview (OPD Task Force 2008), Kernberg's (1984) structural interview, and the interview recommended for psychodynamic case formulation (de Souza and Zytner 2016). In general, these either require the clinician to have additional training or they are performed by psychologists or psychiatrists.

Some data from research in psychotherapy highlight the sense of opportunity that is present in the initial interviews. For example, Barrett et al. $(2008,253)$ report that, of 100 potential patients in contact with a mental health clinic, only 50 will attend an initial assessment, 33 will attend a first treatment session, 20 will remain by Session 3, and fewer than 17 will remain by Session 10 .

Other studies, such as that by Flückiger et al. (2013), discuss the importance of the first interviews for achieving positive results later on. For example, Lutz (2002; Lutz et al. 2006, 2013) suggests the importance of observing a genuine improvement in the feeling of well- being prior to the fourth session.

This all points to the importance of systematically observing the first meetings between the patient and the clinician in order to understand the initial factors that contribute to possible therapeutic failures, as well as those that encourage the development of the psy- choanalytic process. This necessarily requires that the therapist acknowledge his or her responsibility in making decisions about his or her work (Oddli and Rønnestad 2012).

\section{Why analyse clinical material as a group?}

Group exchange constitutes a fundamental contribution to addressing two issues that have long been topics of discussion in psychoanalysis.

The first issue is related to the historic pursuit of Common Ground (Wallerstein 1988, 2005a, 2005b), which Hanly clearly expresses with the following question: "Are there facts about an analytic process that bear on questions of interpretation, theory, and tech- nique upon which adequately trained analysts can agree despite theoretical and technical differences among the discussants and the presenters of clinical cases?" (Hanly 2014, xxi). The second issue, which could be called Convictions, is related to the following list by Leuzinger-Bohleber about the problems with clinical tradition and the determination to resolve them to improve quality:

\footnotetext{
These range from the arbitrary status of clinical observations for buttressing a given theoretical stance or hypothesis; the hazard of hermetically closed viewpoints; narcissistic confirmation, in lieu of the (self) critical reflection of an observation; a gravitation towards "positively resolved" star cases, in contrast with the absence of poorly performed treatments; the danger of (uncon- scious) "fabrication" (especially in cases of training); repetition or conformity to mainstream dis- cussions within the psychoanalytic community and, as a consequence, the disappearance of innovative, unconventional ideas, and much else. (Leuzinger-Bohleber 2014, 125)
}

The International Psychoanalytical Association (IPA) Clinical Observation Committee's 3-LM Work Groups, one of which is comprised of the authors of this article, have developed a model for group work to promote responses to these issues: the Three-Level Model (3-LM) (Bernardi 2014c, 2015). This modality of exchange makes it possible to work as a group to include and analyse sociocultural belonging 
and social subjectivity, with the theoretical loyalties that these entail (Rodríguez Quiroga de Pereira et al. 2007). It is in this same sense that Kantrowitz (2014) maintains that theories are filtered through who we are as people. Groups, then, make it possible to illuminate those aspects-kept invisible behind what is called "common sense"-that produce the social construction of subjectivity (Borensztein 2016).

It is promising that different experiences carried out using the 3-LM show a high degree of group consensus in the assessment of changes in the patient, in line with empirical studies (Leibovich de Duarte et al. 2002; Leibovich de Duarte 2010), especially at the phe- nomenological level (Level 1).

At this level, clinical material tends to have

metaphors or scenes that transmit the core of the patient's problems in a vivid and unsaturated way. Some of these appear from the beginning and become the focus of the therapeutic work - they can be considered "anchor points" that constitute the background upon which subsequent changes can be identified. (Bernardi 2015, 14; italics added)

Fitzpatrick-Hanly (2014), reflecting on work by Ungar (2014), proposes that the concept of an anchor point can be thought of as a new type of clinical narrative.

This kind of group experience, as Gullestad (2014) suggests, lays bare the analyst's "naked" self, revealing details of his or her personal way of working as well as his or her difficulties doing so. In this sense, in addition to reflecting on the material, participants have to work on themselves and on the shared dynamic to resolve the obstacles that the group exchange itself can produce, hindering the task at hand. Favourable conditions are thus created for producing shared analyses in a climate of respect and trust. Thinking extensively about this type of work may be an interesting way to facilitate the presentation of genuine clinical records, considering how difficult obtaining them has historically proven to be. Gullestad's writing evokes the difficulties that Balint (1957) dealt with, which required him to modify his model and emphasise the importance of the group for modifying participants' anxieties and emotions in group experiences.

Balint modified his model when he discovered that the group can serve as a moderator and catalyst to work through the difficulties and anxieties clinicians have when presenting their work with their patients to their colleagues. He expresses this as follows:

Discerning the discrepancy between our actual conduct and our intentions and beliefs is no easy task. But if there is a positive cohesion among the doctors in the group, each member's mis- takes, blind-spots, and shortcomings can be frankly examined and at least partially accepted by the interested party. (Balint 1957; italics added)

\section{Why include empirical tools in the study of the material?}

There are now numerous studies that provide valuable empirical data to demonstrate the usefulness (efficacy and effectiveness) of psychoanalytic treatment (Fonagy 2002; Leuzin- ger-Bohleber and Kächele 2015). Shedler (2010) and Leichsenring and Rabung (2011) have published meta-analyses that bring together evidence from multiple studies, and they conclude that most patients for whom psychoanalytic treatment has been indicated achieve clinically significant changes. However, when this does not occur, there are very few publications that make it possible to investigate why this has happened. Of 455 articles studied using the Inventory of Basic Information on Single Cases (Desmet et al. 2013), only 4\% report treatment failure. 
Based on research in psychotherapy, Lambert (2013) reports that with respect to thera- peutic efficacy, the two factors with the greatest impact are attributable to the patient and the world outside treatment (40\%) and to factors shared with other psychotherapies (30\%), including a positive therapeutic relationship. Bernardi et al. (2016) claim that it is logical to think that these same factors can contribute to treatment failure, and in the same text he notes that occasional errors are specific to each therapeutic process, but their effects can cause diverse types of manifestations, including dropping out of treatment. In this quest to combine perspectives, Referential Activity (RA) (Bucci 2007) makes it possible to examine in depth what takes place in the psychoanalyst's office between the analyst and the patient in order to determine how this interaction is related to the effects of treatment. Similarly, Macdonald (2014) alludes to the limitations of the therapist as expert, report- ing based on the scientific literature both how difficult it is to recognise when a patient is deteriorating and how hard it is to be judged by one's peers in such situations. Hannan et al. (2005) equate the use of instruments for monitoring to paraclinical examinations in medicine, reporting that they can identify $85 \%$ of the patients whose conditions will deteriorate upon finishing treatment by the time they have attended the third session. Bystedt et al. (2014), using an anonymous online survey for cognitive therapists, find that clinicians lack training in detecting the negative effects of therapy and are unfamiliar with the methods and criteria used in current research to identify and prevent attrition and adverse events in psychotherapy. Perhaps something similar is occurring among psycho-dynamic therapists.

In line with these opinions, we propose the systematic observation of empirical data as a resource to complement and enhance the reach of our clinical observations. Roussos and Vallejo consider that studies with empirical support constitute an essential source for vali- dating current clinical knowledge. They clearly express this by indicating that "the ethical obligation to investigate what is really happening in an analysis, what is really therapeutic and under what conditions, remains intact; what is under discussion are the methods" (Roussos and Vallejo 2004, 832).

\section{Study objectives}

Taking into account the frame of reference described in the introduction, and with the objective of analysing the usefulness of empirical criteria for observing psychoanalytic cases, this article describes an experience of systematic clinical observation. Our group selected the first four meetings of a patient called Lara as its focus of observation in order to: (a) recount a group experience of systematic clinical observation; (b) use empiri- cal tools in conjunction with group clinical observations; and (c) generate hypotheses about critical aspects of the therapeutic process, especially those related to potential nega- tive predictors of treatment.

\section{Methods: Sample, materials, and procedures}

\section{Sample}

The units of analysis were the patient's first four interviews. Lara unilaterally discontinued her treatment six months after starting. 
The treatment consisted of long-term psychoanalytic psychotherapy with an initial fre- quency of twice per week, which was later increased to three times a week (de Maat et al. 2013).

With respect to ethical considerations, this study followed the guidelines related to ethical aspects of research put forward by: (a) the Code of Ethics of the Buenos Aires Association of Psychologists (APBA 2013); (b) the Ethical Regulations formulated by the American Psychological Association (American Psychological Association 2010); and (c) Argentina's National Law on Professional Psychological Practice (National Law 23,277 1985). More specifically, work on the design of research methodology in the area of mental health by Leibovich de Duarte (2000) and Roussos, Braun, and Olivera (2013) formed part of the ethical proposal for this study. In Lara's case, informed consent was requested from the patient and the treating analyst, and the study was approved by the Ethics Committee at the Instituto Universitario de Salud Mental (IUSAM, University Mental Health Institute), Psychoanalytic Association of Buenos Aires.

This Psychodynamic Clinical Research Team decided to constitute itself as a clinical observation group for this study because it considers that the objectives proposed by such groups meet the needs of an institutional and theoretical policy it considers to be of great importance (already referred to in describing the characteristics of group work, above).

The open group was formed with four analysts (one in training), of whom three are female psychologists and one is a male psychiatrist. The call to participate in the group was to contribute four verbatim initial interviews with one's own patient. This condition meant that each member would have the opportunity to present his or her unedited work.

In terms of theoretical allegiances, two of the analysts are specialised in bonding and the other two are psychodynamic therapists in the strictest sense.

\section{Materials and procedures}

This study used the Multilevel Observation Model (MOM) proposed by Thomä and Kächele (1987), Kächele and Thomä (1995), and Kächele, Schachter, and Thomä (2009) as its struc- tural foundation. This model was chosen, first, because the multilevel approach to clinical material (MOM) affords a first approximation to the different ways of studying clinical material, some of which are little known by clinicians. This model proposes four levels, as follows:

(A) The analyst's communication about his or her patient

(B) Systematic clinical description; 3-LM was used

(C) Guided clinical judgement procedures; the Shedler-Westen Assessment Procedure (SWAP) was used

(D) Computer-assisted text analysis; Referential Activity (RA) was used.

The Shedler-Western Assessment Procedure (SWAP) (Shedler and Westen 2007) was used because, as its authors explain (Shedler and Westen 2004a, 2004b, 2006, 2007), it offers clinicians the advantage of a shared vocabulary for expressing their observations and inferences about a diagnosis and the personality dimensions of their patients. It also produces a systematised record of clinical observations. 
We also used RA, which alludes to the capacity to express non-verbal experiences, especially emotional experiences, in verbal form. It is a psychological concept from Mul- tiple Code Theory (Bucci 1997). RA was evaluated using both the Discourse Attribute Analysis Program (DAAP), which consists of a computerised text analysis system (Maskit, Bucci, and Roussos 2002), and the S-WRAD dictionary in Spanish, which assigns a given value to words and makes it possible to evaluate high or low levels of RA (Roussos and O'Connell 2005).

Second, 3-LM was used because it is considered by its authors to be a way to triangulate between the observations of the analyst presenting the material and the multiple obser- vations of the material made by the group. It is thus an "observation of an observation," like the work of any clinician. While the temporal perspective (evaluation of the progress of treatment) is a specific contribution of this model, the authors implemented it in this case to evaluate the progress or lack of progress from the first interviews.

\section{Results: Systematic clinical observation in the Lara case}

This section will illustrate our work on the Lara case, following the combined frameworks discussed above.

\section{Level A: The analyst's communication about her patient}

This level includes narratives and clinical vignettes that have been reconstructed by the analyst. The treating analyst's presentation of patient Lara is reproduced below. It is essential to consider that for the analyst, everything that occurs within the sphere of the meetings or sessions forms a part of the unique situation and the frequency and format of encounter that the patient-analyst dyad constructs together. The patient's explicit speech about her reason for the appointment is recounted, as are contradictions that reveal dissociated aspects and behaviour that the patient presents as choices but do not correspond to the emotional cor- relate she demonstrates. The analyst's inferences and questions are also included, which have served as the basis for the construction of some clinical and theoretical hypotheses that later form a part of the discussions and exchanges with the group of colleagues.

The therapist's case report reads:

In the first interview, Lara reports that she made the appointment because she has several conflicts: she is arguing a lot with her 11-year-old daughter, Clara; she is about to separate from her partner Franco for the fifth time; and she often cries about the death of her father, who passed away 6 years earlier. Though her words say that these are situations that deeply affect her, there is an apparent incongruity between what is said and the emo- tionality put into play, which prevents an empathic connection between us.

Examples of how she talks about it include: 'I have several conflicts at the personal level', 'not getting along with a child unleashes everything', 'I am worried about not being able to handle my daughter', 'I feel very apathetic'.

With respect to her background, she relates that she got pregnant when she was very young, she decided to continue with the pregnancy and went to live with Franco, her daughter's father. It seems more like a story about running an errand, which contradicts the fact that she could not tell her family about it until she was five months pregnant, explaining that 'she was ashamed'. She thinks she is repeating her maternal history, as her mother had her sister when she was very young, with one difference: her mother was married. 
She relates situations of violence and abuse, such as when her husband pushed her down the stairs when she was eight months pregnant. There does not seem to be any questioning about what there is about her or the bond between them that produces and/or influ- ences this violence. For her, he is the violent one.

It is difficult to know when she is being sincere, which puts into question the viability of treatment. During the first meeting and later in the meetings that followed, she focuses on her family of origin and on the men in her current life. She says that there is a long history of fights and disagreements that revolve around money and stealing among members of her family. Her sister, she tells, accused her father of having robbed her and they never spoke again. Then her sister also accused the patient's husband of stealing. The entire family works in a field that seems to operate on the edge between legality and illegality.

In the second interview, she says that she is going out with a man, she tries to clarify that she is not unfaithful and that she is not going to make any decisions about the relationship until she decides about her separation. She does not know the man she is going out with well. At the same time, another man she went out with a few years earlier continues to call her, and one night he waited for her in front of her house. And she says: 'He came in his girlfriend's car', attempting to condemn this person's unfaithful conduct. She is not able to question herself, or to see that she is the one who goes in her boyfriends' cars', by maintaining relationships with three men simultaneously.

She does not have solid social ties. She found a certain place of belonging with a group of her daughter's schoolmates' mothers. As the interviews continue, she stops talking about her daughter, and she starts to talk about her separation. She is able to relate that on weekends, when she is alone, especially at night, she gets upset and cries. But she does not allow her emotions to show at all. It causes one to question. Such as, for example: does she get upset?

In this extract, the analyst communicated her first inferences to the group, which were the point of departure for developing the working hypothesis (Leibovich de Duarte 1996, 2006; Leibovich de Duarte et al. 2004). With this report, the group identified some of the analyst's inferences about intrapsychic and relational material with respect to the patient's family situation, as well as prognostic inferences about the future of treatment. No diag- nostic inferences were observed in this report.

\section{Level B: Systematic clinical description}

These are systematic descriptions of a treatment's interviews and sessions. "Verbatim" recordings are used to facilitate systematising and structuring the clinical material. As men- tioned above (see Methods), levels 1 and 2 of the 3-LM were chosen to develop Level B (Ber- nardi 2014c, 2015). This involves identifying the following in the clinical material: (a) the anchor points and their transformations; and (b) the main diagnostic dimensions. Each of these points is described below as they apply to the clinical material in the Lara case.

In this level, the group started reading the material (verbatim transcript) and the group exchange began. The anchor points in the patient material were identified: defining the focal points where it would be expected that the analyst would

intervene, potentially leading to evolution in the first interviews or producing changes over the course of the analytic process. The observation group identified these focal points from the first interview and explored what was happening with them in the material from the rest of the interviews, paying special attention to

the fluctuations or modifications that became evident in the words of both the patient and the therapist as well as in the interaction between them. In this way, we sought to describe any possible transformations in a phenomenological 


\section{Focal Point A: related to difficulties in interpersonal relationships. Focal Point B: related to the patient's ethical understanding. \\ Focal Point C: related to problems with the regulation of behaviour and the patient's affective/impulsive response.}

Anchor points A, B, and C were agreed upon based on the material from the first inter- view. Table 1 illustrates the clinical material that corresponds to each focal point observed and agreed upon.

Table 1. Anchor points.

A. Anchor point: Interpersonal relationships

Text to introduce the anchor point: Start of the first meeting. Relationships with others are a situation of conflict for the patient. When the other acts as separate from her, she seems to experience it in a somewhat paranoid way that is expressed with physical and verbal violence. It can be inferred that her daughter's puberty, by modifying the previous bond between them, becomes a situation that can be felt as a threat.

Example (edited text from the verbatim transcript): $<P 2>$ Do you want to tell me why you are here?

$<P 1>$ I don't know where to start. Well, I have several conflicts at the personal level. Like I have an eleven-year-old daughter and she is at a very difficult age, aside from that I am getting separated and my daughter is leaning a lot towards her father, so we are like at war. It's like a constant, but aggression all the time. The truth is that I already have enough problems, with my father's death a few years ago, several things. But like I decided to start therapy because I think that not getting along with a child is what unleashes everything. I don't have any patience with my daughter and I notice that I don't have any patience with her reactions toward me, reactions of constantly attacking, its like I $m$ her 'punching ball all the time....

$<P 1>\ldots$ and she was a kid who was super stuck to me, in my family they even called her my burr, ${ }^{a}$ because she was my little burr. She used to go everywhere with me and its like I feel like the relationship is getting away from me and I don't know how to handle it with her. I want to punish her but I also say, 'poor little thing, what she's got going on in her head' in order to have such angry reactions, like ... you know when you feel like they have this hate and you say 'this can't be my daughter'.

\section{B. Anchor point: Ethical understanding}

Text to introduce the anchor point: When the patient reports how her family hides some information from her, her speech is ambiguous, contradictory, and ambivalent. In addition, it insinuates a transferential allusion to theft that could be taken as the possibility of a false transference connection.

Example (text edited from the verbatim transcript):

$<P 2>$ But do you think of it like a kind of fatal destiny, or do you think that you, let's say, you make a type of choice that leads to the model being similar? What do you think? How would you put it?

$<P 1>$ I donit know, I think that, I don't know if the model is similar, but they never end up telling me what is really going on. It's not that they say: 'okay, look, let's see, Franco used to work with me and what did he do, he took the clients, the database, and he gave it to someone else, I don't know. As if I told another psychologist to take all of your patients' information'. They never told me, I tried to ask and I sat down with my sister and my mother and I said: 'okay let's see, can you tell me what happened?' 'No, were never going to tell you, I don't want this to be the reason that you separate from your daughter's father'. I explained to them: 'lets see if we understand each other, this isn't the reason for our separation. I want to know what happened, I want to know who Im with'. Its like a back and forth. And I hide things and they hide things from me, so I never really know what is happening, then I go and talk to Clara's father: 'You stole from my sister'. 'Are you crazy? he says, 'I didn't steal from anyone. Your sister because she's crazy'. And I also think: 'Wow, eh, the same thing happened with my father, and with my husband the same thing is happening?'

\section{Anchor point: Emotional regulation}

Text to introduce the anchor point: There seems to be some confusion in understanding and differentiating between the emotions at play with others and within herself, along with confusion between aspects of the external world and the internal world, which is manifested in impulsive behaviour.

Example (text edited from the verbatim transcript):

$<P 2>$ What does it mean that you have one situation and he has another?

$<P 1>$ We have different salaries. I might make twice as much as him, so for me, I can stay in the apartment and pay for all the 
expenses, a cleaning lady to work at my house all day, school, you know, a car, everything that, the expenses that one might have. My daughter witnessed several of her father's aggressive fights with me, so I feel like between my daughter and I there isn't that respect anymore, like I $m$ her friend and like, and right away she gets defensive 'don't hit me' and I don't touch her. So, I'm like forgiving her for everything because I understand the problems she must have in her little head.

Aside from all of the personal problems that I have: the issue of the separation, the issue of a failed marriage, this is the fourth time I am getting separated from the same man. I' $m$ worried about the issue of my relationship with her because now she is eleven and I can see that I can't handle her.

$<P 2>$ What do you suppose? You just clarified for me quite vehemently that you do not hit her, so, what do you think brings her to say to you 'don't hit me'?

$<P 1>$ Because her father, sometimes, his reaction is to pull her hair or slap her, l' $m$ the opposite of that, I' $m$ about the punishment, take away her cell phone, things that hurt without hurting her, but her cell phone is her world, her life, I took it away from her and so now she's like angry, like I $m$ her enemy. Not recently, but a few months ago she saw very aggressive things at my house: breaking things, me raising my hand to my daughter's father; my daughter's father's name is Franco.

${ }^{a} \mathrm{~A}$ burr is a prickly seed that sticks to clothing and is difficult to remove.

By monitoring the anchor points across the four interviews, the group agreed that no indicators of progress could be seen (Liberman 1972) that reflected any incorporation of the analyst's interventions: not in the patient's perception of the conflicts at which the inter- ventions were aimed (either at the time or from what she could infer when reviewing them in light of her life crises); not with respect to the defences she implemented against these conflicts; and not in the patient's degree of awareness of these conflicts. Furthermore, no improvement was observed in the patient's subjective wellbeing over the course of the interviews, nor was any progress noted between them. This was considered to be a negative predictor of treatment with respect to the compatibility of the therapeutic pair.

Below, we discuss our work to identify the main diagnostic dimensions in the Lara case. For the specific case of this patient's problem, a good part of identifying the diagnostic dimensions dealt with questions closely related to the form of presentation of transference and countertransference. At this level of the discussion, the group classified the patient's mental behaviour as falling within the following dimensions: histrionic, psychopathic, and borderline, considering the material available to be insufficient for establishing a definitive diagnosis. According to this group conceptualisation, the case was characterised as follows:

The patient presented low disease awareness, with a contextual, romantic, and family situation that contributed to her psychopathological functioning.

Her main conflicts were identity-related and oedipal, oscillating between submission and control. Her central defences were dissociation, projective identification, denial, and omnipotent control.

A low level of symbolisation and creativity predominated. Her connection to her internal representations and her interpersonal relationships was unstable, superficial, and poorly differentiated.

Her ideas and values prevented her from processing her emotions comprehensively, not allowing her to perceive herself or others properly.

Her interpersonal relationships were confusing and indiscriminate, with difficulties with intimacy. Lying and hiding interfered with her interpersonal relationships in general and with the therapeutic relationship in particular. Lying generated confusion and ambivalence in the analyst.

It is also important to consider the relevance of the intervening professional's experi- ence when constructing diagnostic criteria, in addition to the professional's 
to engage with the other and his or her flexibility with respect to sustaining norms and values that can accommodate each patient's singularity (Borensztein 2008). These points were used to understand this patient.

\section{Level C: Guided clinical judgement procedures}

This is a necessary step in order to be able to transform qualitative data into "measurable" quantitative data. The SWAP diagnostic tool (Shedler and Westen 2007) designed by Shedler and Westen (2004a, 2004b, 2006) was used here.

Taking into account the diverse diagnostic hypotheses that arose from the analysis at the previous level (histrionic, psychopathic, and borderline personality), the system- atisation afforded by the SWAP allowed the group to observe which diagnostic hypoth- esis would prevail at the quantitative level. The SWAP yielded the highest scores for precisely the three differential hypotheses discussed in the group, but it showed a pre- ference for one of them (histrionic personality). The use of guided clinical judgement

Table 2. SWAP results: Diagnosis of personality (DSM IV).

\begin{tabular}{lc}
\hline Personality disorder & $\mathrm{T}$ \\
\hline Histrionic personality disorder & $\mathrm{T}=70.98$ \\
Antisocial personality disorder & $\mathrm{T}=68.25$ \\
Narcissistic personality disorder & $\mathrm{T}=66.25$ \\
Borderline personality disorder & $\mathrm{T}=65.06$ \\
Passive-aggressive personality disorder & $\mathrm{T}=60.77$ \\
Paranoid personality disorder & $\mathrm{T}=60.60$ \\
\hline
\end{tabular}

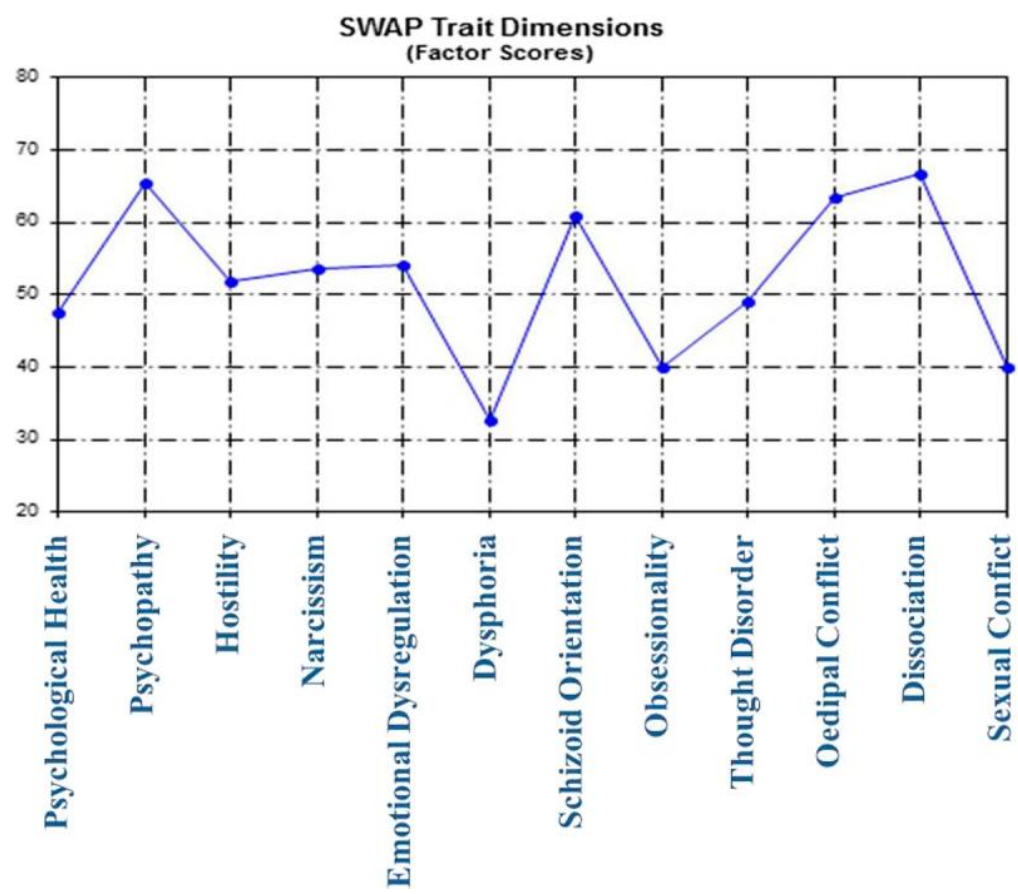

Figure 1. Scores for features of psychological functioning according to the SWAP. Note: Shedler J, Westen D. SWAP-200 for Microsoft Excel, @ 2015 SWAP assessment LLC | Shedler-Westen Assessment Procedure, http://swapassessment.org. 
procedures such as the SWAP thus made it possible to narrow down our diagnostic impressions and specify a predominant diagnosis for the patient. Table 2 shows the six highest scores obtained with the SWAP (using SWAP-200 for Microsoft Excel) (Figure 1).

\section{Level D: Computer-assisted text analysis}

The objective of this level is to help resolve classification issues using computer systems and programmes. We decided to evaluate RA to account for this level of analysis. Bucci (1997) explains that variation in the levels of RA serves as an indicator of the capacity to commit to therapeutic treatment, as well as constituting a way to monitor the effective- ness of the process.

In this article, we understand the evaluation of RA to have made it possible to identify the effect of the analyst's different interventions on the patient and on the process, per- mitting clinically useful observations. Table 3 shows a segment of the discursive inter- action between patient and therapist from the second meeting, related to the anchor point initially called "ethical understanding."

Figure 2 shows the variation in RA over three patient-therapist exchanges. In interven- tion 1, we can note how the therapist intervenes by laughing in a spontaneous and genuine manner. In this way, she expresses that she paid attention to the fact that the

Table 3. Anchor point B: Ethical understanding. Segment from the second meeting (from word 5005 to 5469).

\footnotetext{
Example (text edited from the verbatim transcript):

$<P 1>+$ The thing is they would say it in a nice way, they werent saying it in a bad way but there comes a time when it's already like, one time I stopped my mother's husband, he says to me: 'III give you a boot so you can kick your husband out- this guy you have in your house you kick him out. And I said: 'wait, I don't meddle in your lives, let me resolve it Im thirty-one' I have to ...

$<P 2>+$ there you were able to say ...

$<P 1>$ I have to, I stop my mom too sometimes, I have to take charge a bit, 'leave me alone' like, so my mom said to me: 'if you're going to go to the psychologist, start seeing a psychologist, I think its great Im thrilled, but don't lie to the psychologist.

$<P 2>\mathrm{Haha}$
}

INTERVENTION 1 IN FIGURE 2

<P1> I said: 'look mom if I go to a psychologist I' $m$ not going to lie, I $m$ not going to say that my life is all rosy because he's going to say to me: "girl, what are you coming here for?".

$<$ P2> And, why do you think your mother told you not to lie to me?

INTERVENTION 2 IN FIGURE 2

$<P 1>$ Because Im, though Im not a liar, but maybe sometimes my mother calls me on a Sunday morning and I say: 'no mom I'm great I $m$ here at home, I $m$ going to get together with my friends' and I might be alone, but if I say 'no, I $m$ alone at home' she starts 'I $m$ coming over' 'and III pick you up and we'll eat and you know how, poor her she worries, but its like I want to have space for myself, Ive always said: 'yes okay III go, III go, if it's my sister III go, III take the kids to school for you, III pick them up' it's like now I say: 'no, enough, I want to think about myself a bit.

$<P 2>$ I think it's also a message that you're sending me, that, even though you tell me that you felt comfortable and that you thought I was cool, I don't know, I think you are also telling me: 'look, but let's follow my timing, give me time because you know that if not, I can leave and I cannot tell you everything', right?

INTERVENTION 3 IN FIGURE 2

$<P 1>$ No, but you're going to start to realise with me what l'm like uhh, okay you're going to start to realise by yourself if you see that uhh, when I tell you, when I don't tell you uhh, the truth is that now that I made up my mind to start and I made up my mind, I hope we can continue and its great that, that you accept me as a patient and I [accept you] as a professional and, but the truth is that I made up my mind to start above all for me, before I would always start with others, for in order to see what had happened in my previous life and my father and my siblings and my mother. 


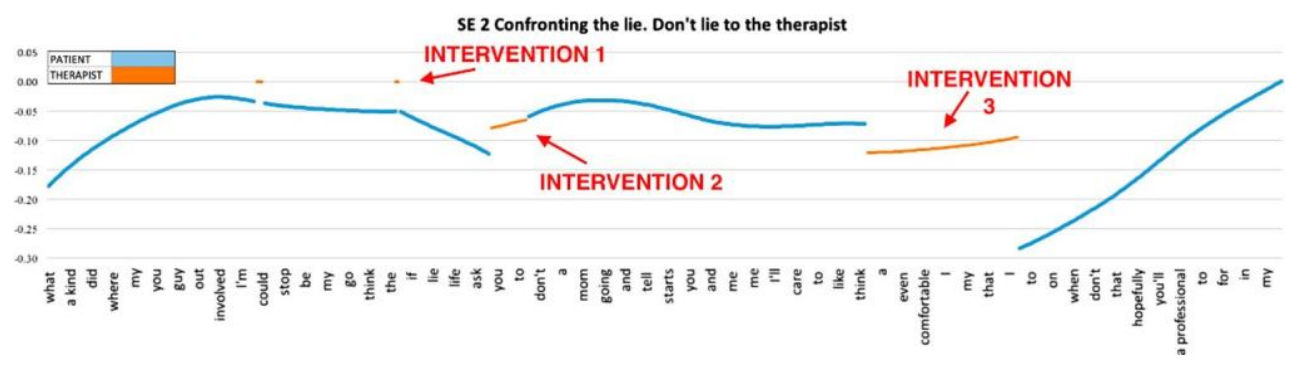

Figure 2. Referential activity.

patient tends to lie. This type of interaction mediated by humour and spontaneity creates a break in the patient-controlled discourse. Intervention 2-"And, why do you think your mother told you not to lie to me?"-attempts to promote greater reflection by the patient about what she is recounting. What is observed when using this tool is that the lie operates as a defensive organiser. Intervention 3 refers to the patient's interpersonal relationship with the therapist and, by hinting at possibly leaving treatment or deceiving the therapist, clearly specifies what components to consider as prognostic indicators. The RA shows how the patient's discourse becomes disfluent when the analyst has an impact on her. This type of intervention is the most effective for this patient, as there is a break in the discursive modality and, during the initial moments of treatment, it encourages the development of the therapeutic alliance, as proposed by level 3 of the 3-LM.

The contents of this sequence show the patient's deceitful and dishonest aspects, in line with the high values of the psychopathic dimension yielded by the SWAP. The system- atisation of the data also reflects the ethical dimension that had been selected as an anchor point using levels 1 and 2 of the 3-LM model in the methodology proposed by Bernardi (2014c, 2015).

\section{Integration of the levels: Hypotheses about potential negative predictors of treatment for the Lara case}

As explained above, one of the focal points for the group clinical observation consisted of identifying the aspects of the clinical case that could function as negative predictors of treatment, taking into account that the patient stopped her treatment six months after initiating psychotherapy. The group thus began to select and agree on possible indicators at each level of observation from the first four interviews that might relate to the patient subsequently dropping out. Table 4 summarises the indicators selected by the group.

Table 4. Selected indicators. 


\section{Discussion}

Our discussion analysed what contributions systematic clinical observation may have for the patient, for the treating therapist, and for the observation group. More generally,

we also dis- cussed the implications for clinical practice, therapist training, and research in psychoanalysis. The exploratory and preliminary nature of this study must be mentioned as a limitation. With respect to future studies, we consider the use of empirical tools that can be easily implemented by the clinician to be an important contribution to the modality of systema- tic group observation, facilitating the psychodynamic case formulation right from the initial interviews up to an evaluation of the progress of the case.

\section{Possible contributions for the patient}

In the Lara case, our work has helped promote an in-depth discussion. Reviewing Stein's (1972, cited in Kächele and Schachter 2014) list, which includes the considerations in Bergin's (1963) article about the factors that can negatively affect the outcomes of psy- chotherapy, allowed these factors to be considered as contributions for the patient. The first was to clarify the diagnostic criterion for the patient.

We were able to identify problems with impulse control, a predominance of dissociative defences, and significant narcissistic, histrionic, and psychopathic features. We consider this diagnostic accuracy to be an essential starting point for a proper understanding of the patient, which would have led to a better plan for her treatment. Along these lines, numerous studies suggest that good case conceptualisation is associated with the effec- tiveness of treatments (Thomä and Kächele 1987; Lambert and Ogles 2004; OPD Task Force 2008; Levy et al. 2014).

The patient also obtained points for borderline personality, though with lower scores. It is known that people with borderline personality form more intense and unstable relation- ships compared to other diagnostic groups. Kächele and Schachter (2014) report on this, citing the work of the following authors: Skodol, Buckley, and Charles (1983) report a 67\% dropout rate among borderline patients after three months of psychotherapy. Waldinger and Gunderson (1987) found a 46\% dropout rate at six months; only one third of their sample completed their treatment. Similarly, Gunderson et al. (1989) report that $52 \%$ of borderline patients left treatment after six months. Smith et al. (1993) found dropout rates from $31 \%$ to $36 \%$ at three and six months, respectively, for borderline patients. However, Stevenson and Meares (1992) claim that using a psychology of self reduces the dropout rate of attrition to only $16 \%$ at three months.

This result makes it necessary to think about both the therapeutic indication and the type of interventions that should be carried out. In the Lara case, systematic clinical obser- vation made it possible to better differentiate between the different effects of possible interventions; that is, it helped identify the most appropriate type of interventions for the patient. More specifically, we were able to observe that those interventions that created a certain mobilisation of the patient's defensive discourse, with respect to tricks and deception, had a greater impact on her. In turn, these interventions took transference into account. These results allow us to think about the usefulness of specifying the type of interventions to prioritise right from the start in patients with diagnostic characteristics like Lara's, who may benefit from interventions focused on transference, following Kernberg's 
(1984, 1999) work on this issue. Recent research on the differential effects of interpret- ations when based on transference follows this same line (Höglend and Gabbard 2012). This debate is ongoing, however, as other perspectives such as that of Kächele and Schachter (2014) warn about the negative contribution of certain techniques that chal- lenge habitual defences, especially for patients with borderline disorders. Different studies with borderline patients (Horwitz 1974; Weber, Bachrach, and Solomon 1985; Fonagy et al. 1996, cited in Kächele and Schachter 2014) report that there is sometimes a worsening of patients' conditions and that therapeutic techniques are probably respon- sible for this decline, which does not minimise the fact that the patients' characteristics also come into play, as does the ever-present singularity.

Beyond the theoretical position that a clinician takes into account when making the therapeutic indication, the systematic study of the patient also plays a role, further speci-fying the criteria already mentioned at the start of this article that are established in the initial interviews (diagnosis, degree of analysability, prognosis, indications, and therapeutic strategies).

Returning to Stein's (1972, cited in Kächele and Schachter 2014) list, the second point- external conditions, in this case Lara's extended family and her work (also with her family) - took on real prominence. There was a family dynamic in which the pursuit of truth was obstructed by a family narrative that did not seem to allow any questioning or clarification. Stealing and hiding permeated her narrative without being questioned, at least from the patient's perspective.

For the third point, the constitutional factor, the concept of borderline as well as that of psychopathy suggest modalities of personality functioning conditioned by elements at this constitutional level. They are often considered to be structures of personality function- ing that, when diagnosed, imply specific symptoms and specific prognoses.

Of the adverse modifications of the ego that lead to severe personality disorders - Stein's fourth point-the patient had impaired ego integration, which caused splitting.

With respect to Stein's fifth point, transference in Lara was unstable and fundamentally distrustful and evasive, which was expressed countertransferentially in the analyst's initial report: It is difficult to know when she is sincere. This permeates the initial interviews and is put into play in the pursuit of interventions that can confront her inconsistencies, using humour as an ally. The RA analysis notes this, and this insight would have encouraged a review of the complementarity of the therapeutic pair, making a positive contribution to the treatment.

Finally, and by way of hypothesis, if systematic clinical observation had been carried out while the treatment was still in progress, the identification of potential predictors of patient attrition could have been used to try to prevent the patient from ultimately drop- ping out of treatment. It is also important here to consider the invaluable contribution that the psychodynamic case formulation could make if added to the patient's clinical record, both for the patient and for a later therapist.

In any case, the issue of predictors of attrition, as well as considering the predictive hypotheses related to the complementarity of the therapeutic pair (Liberman 1972) and prognostic judgement about the type of interventions to apply (Roussos, Boffl Lissin, and Leibovich de Duarte 2007; Juan 2014), constituted significant contributions for both the treating therapist and the clinical observation group. 


\section{Contributions for the clinical work of the treating therapist}

For the therapist, a first contribution of the work carried out here derives from the very presentation of her own case to a group. This created a great deal of work and commit- ment among her colleagues. Analysing a systematically recorded case using audio record- ings and transcripts of the sessions entailed an unprecedented level of exposure for the therapist. The positive aspect of this exposure lay not only in creating group care for the treating therapist, but also in adding the group perspective to the conceptualisation of the case and to the overall training of the therapist. Following Altmann (2014), the pres- entation of recorded cases is a necessity in our discipline, and, further, it can constitute a space of professional respect, trust, and exchange. Overall, systematic observation made it possible to demystify the analytic process, revealing the concrete difficulties of clinical practice and the natural evolution of a case (see, for example, Kächele et al. 2006).

As mentioned above, and given that this case ended prematurely at six months into treatment, another contribution for the treating therapist was the ability to hypothesise, retrospectively, about the possible indicators of dropout. In this sense, learning from patients who drop out of treatment can be a way to improve therapeutic abilities and to promote curiosity and interest in the phenomenon among peers and institutions (Olivera et al. 2013; Roos and Werbart 2013). Similarly, studies by Lambert (Lambert et al. 2001; Hawkins et al. 2004; Lambert 2007) and the work of Lutz et al. (2006) emphasise the importance of providing the therapist with information about the course of treatment.

\section{Contributions for the observation group}

The experience of this particular clinical observation group permitted an examination of its members' explicit theories and implicit ideas (Sandler 1983; Zysman et al. 2009) about the patient under study, which led them to jointly investigate hypotheses they thought could have led to progress in the interviews with the patient.

The group exchange, like any exchange between people, puts emotional regulation into play. Those who participate in such an experience must engage in work that will allow them to connect. In the experience described in this article, the members of the group were exposed to a variety of emotions. On one hand, caring for the analyst who offered her clinical material was present at all times. We could also say that, in some way, while the experience was under way, the patient became "everyone's patient" or "the agreed-upon patient," putting into play the difficulties-one's own and others'- inherent in clinical work. These aspects are in line with the current positions held by the International Psychoanalytic Association in terms of including clinical group observation and discussion in analyst training (Hanly and Hanly 2001; Altmann 2014).

When there was a certain discrepancy between the analyst's account and the group's work on the clinical material, a sincere and committed exchange took place among the group, not only with respect to thinking about the differences that arose, but also in caring for the therapist and recognising the exposure of her work, with the personal impli- cations this has for the analyst (Jiménez 2007). This latter point is an important contri- bution of group work, as the line that separates the debate of ideas from opinions about the person expressing the ideas is not always clear. In this sense, the experience 
of clinical observation groups is a training field for learning how to engage in dialogue, exchange, and discussion about different ways of thinking, creating fertile spaces for the personal and professional growth of those who participate and generating accessible conditions for the accommodation of diversity. In the case of this working group, though the participants were all trained at the same institution, it was nonetheless necessary to review our theoretical affinities at each level of work with respect to the challenges each level presented.

In general terms, it would not have been the same to analyse the case in a nongroup manner. Systematic clinical observation added much greater depth to our understanding of the clinical material, broadening our perspectives for conceptualising the case and gen- erating working hypotheses. In particular, identifying the focal point related to ethics was an outcome of the group work.

For the group, the involvement of the treating therapist meant having a key informant during the analysis of the case. This led to an exchange that allowed the therapist and the group to become aware of blind spots (conflicts in the analyst that the analyst is only par- tially aware of), hard spots (conflicts due to supporting a single theory and technique), and dumb spots (conflicts that have not yet been detected) related to certain characteristics that a patient brings and puts into play as a function of a therapist's characteristics (McLaughlin 1991; McLaughlin and Johan 1992).

\section{By way of conclusion: Implications for clinical practice, training, and research in psychoanalysis}

The systematic clinical observation work described in this article responds to a current need in contemporary psychoanalysis for clinicians to be able to systematise the analysis of their cases. This task is difficult due to the frequently poor methodological training of analysts. In turn, how clinicians process their patients' material and identify any biases they may have remains an unresolved issue (Roussos, Boffl Lissin, and Leibovich de Duarte 2007; Juan 2014). In this sense, this work is intended as a first attempt at specifying the issues of methodology and knowledge transfer that form a part of clinical psychoana- lytic practice.

The systematic observation of a clinical case constitutes a way to begin to connect clinic and research in psychoanalysis, as it positions the analyst as both researcher and research subject simultaneously (Zukerfeld 2014). This research also makes it possible to position psychoanalysis more solidly in the field of science, where a more systematic study of psy- choanalytic postulates and procedures is still necessary (Lancelle 1997; Roussos and Vallejo 2004).

At the same time, this greater systematisation can have positive repercussions for the training of analysts, encouraging them to seek consistency between the conceptualisation, operationalisation, and measurement of change in the therapeutic process (Wallerstein 2006).

In short, these types of studies meet the need to move from case narratives to systema- tic, empirical case analyses (Kächele, Schachter, and Thomä 2009), which, from the point of view of this article, is a way to enhance the methodological professionalism of our discipline. 


\section{Translations of summary}

Avec l'objectif d'analyser dans quelle mesure les critères empiriques sont utiles à l'observation de cas psychanalytiques, l'auteur de cet article décrit l'expérience d'observation clinique systématique menée par l'équipe de recherche en clinique psychodynamique de I'Institut universitaire de santé mentale (IUSAM) de l'Association psychanalytique de Buenos Aires (ApdeBA). Un groupe de quatre thérapeutes psychanalystes, y compris le thérapeutetraitant, a analysé de façon systématique les quatre premiers entretiens de la cure psychanalytique d'une patiente âgée de 32 ans, qui se sont déroulés à Buenos Aires (Argentine) ; cette cure a été interrompue au bout de six mois. Afin de systématiser l'information, le groupe de thérapeutes a eu recours aux schémas conjugués du Modèle d'observation à multiples niveaux (Thomä y Kächele 1989 y 1997; y Kächele et al., 2009) et du Modèle à trois niveaux de Bernardi (3 L-M Bernardi, 2015a y 2015b). En outre, le groupe a utilisé le système informatique d'analyse de textes DAAP - programme d'analyse des attributs du discours (Maskit, Bucci y Roussos, 2002) - pour mesurer l'activité référentielle. En ce qui concerne l'outil diagnostique, il s'est servi de SWAP - le procédé d'évaluation de Shedler et Westen (Shedler y Westen 2004, 2006). L'auteur de l'article décrit l'application de ces ressources à l'analyse des quatre entretiens et donne des exemples extraits du matériel clinique. II examine également les hypothèses émises par le groupe d'observation clinique et l'utilité des échanges au sein du groupe quant à la compréhension du processus thérapeutique dans son ensemble. Enfin, il discute des effets de ce type d'étude systématique de cas sur la pratique clin- ique, la formation et la recherche en psychanalyse.

Mit dem Ziel, die Nützlichkeit empirischer Kriterien für die Beobachtung von Psychoanalysefällen zu analysieren, beschreibt dieser Artikel eine systematische klinische Beobachtung, die von dem Psy- chodynamic Clinical Research Team at the Psychoanalytic Association des Institute of Mental Health an der Universität Buenos Aires (Instituto Universitario de Salud Mental, IUSAM) durchgeführt wurde. Eine Gruppe von vier psychoanalytischen Therapeuten einschließlich der Behandlerin nahm systematische Analysen der ersten vier Interviews in der psychoanalytischen Behandlung einer 32- jährigen Patientin vor. Die Therapie fand in Buenos Aires, Argentinien, statt und wurde sechs Monate nach Beginn abgebrochen. Wir benutzten kombiniert das Multilevel Observation Model (Thomä und Kächele 1989, 1997; Kächele et al. 2009) und Bernardis Three-Level Model (3LM) (Bernardi 2015a, 2015b), um die Daten zu systematisieren. Wir arbeiteten zudem mit einem computergestützten Tex- tanalysesystem, dem Discourse Attribute Analysis Program (DAA?) (Maskit et al. 2002), um die Refer- enzaktivität zu messen. Das Shedler-Westen Evaluation Procedure (SWAP) (Shedler und Westen 2004, 2006) wurde ebenfalls als Diagnoseinstrument herangezogen. Wir beschreiben die Anwen- dung dieser Hilfsmittel auf unsere Analyse der vier Interviews und illustrieren sie mit klinischem Material. Wir erläutern sowohl die Hypothesen, die unsere Beobachtungsgruppe entwickelte, als auch die Nützlichkeit des Gruppengesprächs für das allgemeine Verständnis des therapeutischen Prozesses. Abschließend diskutieren wir die Implikationen einer solchen systematischen Fallstudie für die klinische Praxis, die Ausbildung und die Forschung in der Psychoanalyse.

Con l'obiettivo di analizzare l'utilità dei criteri empirici per l'osservazione di casi psicoanalitici, il pre- sente articolo descrive un'esperienza di osservazione clinica sistematica effettuata dal Gruppo di Ricerca di Clinica Psicodinamica dell'Istituto Universitario di Salute Mentale (IUSAM), parte dell'Asso- ciazione Psicoanalitica di Buenos Aires. Un gruppo di quattro terapeuti di indirizzo psicoanalitico, di cui faceva parte anche la terapeuta che aveva in cura i pazienti, ha condotto un'analisi sistematica dei primi quattro colloqui di una paziente di 32 anni. II trattamento, svoltosi a Buenos Aires, è stato inter- rotto a sei mesi dal suo inizio. Per sistematizzare le informazioni raccolte il gruppo ha utilizzato il Modello di Osservazione Multilivello (Thomä e Kächele 1989, 1997; Kächele et al., 2009) e il Modello a Tre Livelli di Bernardi (3 - LM)(Bernardi 2015a, 2015b), combinandoli tra loro. Inoltre, per la misurazione dell'Attività Referenziale il gruppo si è valso di un sistema computerizzato per l'analisi linguistica - Discourse Attribute Analysis Program (DAAP) (Maskit et al., 2002). Come stru- mento diagnostico è stata usata anche la procedura di valutazione di ShedlerWesten (SWAP) (Shedler and Westen 2004, 2006). L'articolo descrive nel dettaglio il modo in cui questi strumenti sono stati applicati all'analisi dei quattro colloqui, presentando inoltre alcuni esempi di materiale clinico. Vengono quindi vagliate sia le ipotesi formulate dal gruppo di osservazione clinica sia l'utilità degli scambi di vedute all'interno del gruppo ai fini della comprensione del processo terapeutico. Si discutono infine le implicazioni che questo tipo di studi sistematici di singoli casi clinici può avere per la pratica clinica, per la formazione e per la ricerca psicoanalitica. 
Con el objetivo de analizar la utilidad de criterios empíricos para la observación de casos psicoana- líticos, este artículo describe una experiencia de observación clínica sistemática realizada por el Equipo de Investigación en Clínica Psicodinámica del Instituto Universitario de Salud Mental (IUSAM) de la Asociación Psicoanalítica de Buenos Aires (APdeBA). Un grupo de cuatro terapeutas psicoanalíticos, incluida la terapeuta tratante, analizaron de manera sistemática las primeras cuatro entrevistas de un tratamiento psicoanalítico de una paciente mujer de 32 años de edad, llevado a cabo en la Ciudad de Buenos Aires, Argentina; el cual fue interrumpido a los seis meses de su inicio. Se utilizaron los esquemas combinados del Modelo de Observación Multinivel (Thomä y Kächele 1989 y 1997; y Kächele et al., 2009) y del Modelo de Tres Niveles de Bernardi (3 L-M Bernardi, 2015a y 2015b) para la sistematización de la información. Además se utilizó el sistema computarizado de análisis de textos DAAP: Programa para el Análisis de Atributos del Discurso (Maskit, Bucci y Roussos, 2002) para medir la Actividad Referencial. Y como herramienta diag- nóstica se incluyó el SWAP: Procedimiento de Evaluación de Shedler y Westen (Shedler y Westen 2004, 2006). Se detalla la aplicación de estos recursos al análisis de las cuatro entrevistas estudiadas, brindando ejemplos de material clínico. Se analizan las hipótesis a las que el grupo de observación clínica llegó y la utilidad del intercambio grupal para la comprensión del proceso terapéutico en general. Finalmente, se discuten las implicancias de este tipo de estudios sistemáticos de caso para la práctica clínica, la formación y la investigación en psicoanálisis.

\section{References}

Altmann, M., ed. 2014. Time for Change: Tracking Transformations in Psychoanalysis - the Three-Level Model. London: Karnac. [(2015). Tiempo de cambio: Indagando las transformaciones en psicoanálisis: El modelo de los tres niveles. London: Karnac.].

American Psychological Association. 2010. Ethical principles of psychologists and code of conduct [Internet]. Available from: http://www.apa.org/ethics/code/principles.pdf.

APBA (Asociación de Psicólogos de Buenos Aires). 2013. Código de ética [Code of ethics] [Internet]. Available from: http://www.psicologos.org.ar/docs/Etica.pdf.

Balint, M. 1957. The Doctor, his Patient and the IIIness. New York: International Universities Press. [(1961). El médico, el paciente y la enfermedad. Buenos Aires: Libros básicos.].

Baranger, M., W. Baranger. 2008. The Analytic Situation as a Dynamic Field. Int J PsychoAnal 89 (4):795-826. [(1969). Problemas del campo psicoanalítico [Problems of the analytic field]. Buenos Aires: Kargieman.].

Barrett, M. S., W. J. Chua, P. Crits-Christoph, M. B. Gibbons, and D. Thompson. 2008. "Early Withdrawal From Mental Health Treatment: Implications for Psychotherapy Practice." Psychotherapy: Theory, Research, Practice, Training 45 (2):247-267.

Berenstein, I., and J. Puget. 1997. "Las Entrevistas previas a la iniciación del tratamiento [The inter- views prior to the start of treatment]." In Lo vincular. Clínica y técnica psicoanalítica [The vincular. Psychoanalytic clinic and technique], 77-116. Buenos Aires: Paidós.

Bergin, A. E. 1963. "The Empirical Emphasis in Psychotherapy: A Symposium. The Effects of Psychotherapy: Negative Results Revisited." Journal of Counseling Psychology 10 (3): 244-250.

Bernardi, R. 2010. DSM-5, OPD-2 y PDM: Convergencias y divergencias entre los nuevos sistemas diagnósticos psiquiátrico y psicoanalíticos [DSM-5, OPD-2 and PDM: Convergences and diver- gences between psychiatric and psychoanalytic diagnostic systems]. Revista de Psiquiatría del Uruguay [Uruguay Journal of Psychiatry] 74 (2):179_ 205.

Bernardi, R. 2014a. La formulación clínica de caso. Su valor para la práctica clínica [Clinical case for- mulation: Its value for clinical practice]. Revista de Psiquiatría del Uruguay [Uruguay Journal of Psychiatry] 78:157.

Bernardi, R. 2014b. Formulación de caso. Jornadas de investigación del Departamento de Investigación IUSAM. Clínica psicoanalítica e interdisciplina. [Case formulation. IUSAM Department of Research, Conference on Psychoanalytic and Interdisciplinary Clinic]. July 2014, Buenos Aires, Argentina.

Bernardi, R. 2014c. "The Three-Level Model (3-LM) for Observing Patient Transformations." In Time for Change: Tracking Transformations in Psychoanalysis - the Three-Level Model, edited by M. Altmann, 
3-34. London: Karnac. 2014 [2015. El modelo de los tres niveles para observar las transformaciones del paciente (3-LM). In: Altmann M, editor. Tiempo de cambio: indagando las transformaciones en psicoanálisis: el modelo de los tres niveles, 3-34. London: Karnac.].

Bernardi, R. 2015. La evaluación de los cambios del paciente. El modelo de los tres niveles (3-LM) [The evaluation of changes in the patient: The three-level model (3-LM)] [Internet]. Mentalización. Revista de psicoanálisis y psicoterapia [Mentalisation. Journal of psychoanalysis and psychotherapy] 4: 1-16. Available from: http://www.revistamentalizacion.com/ultimonumero/abril2015/bernar di.pdf.

Bernardi, R., B. Varala, D. Miller, R. Zytner, L. de Souza, and R. Oyenard. 2016. La formulación psicodinámica de caso: su valor para la práctica clínica. [Psychodynamic case formulation: Its value for clinical practice]. Montevideo: Grupo Magro.

Bleger, J. 1971. Temas de psicología: (entrevista y grupos) [Psychological themes: The interview and groups]. Buenos Aires: Nueva Visión.

Borensztein, L. 2008. El manual psicodiagnóstico (PDM) y su utilización clínica. llustración clínica [The psychodynamic diagnostic manual (PDM) and its clinical use: Clinical illustration]. In El Manual Diagnóstico Psicoanalítico. Discusiones sobre su estructura, su utilidad y viabilidad [The psychody- namic diagnostic manual: Discussions about its structure, usefulness and viability], edited by H. Ferrari, G. Lancelle, A. Rodríguez Quiroga, A. Roussos, and L. Borensztein, 32-42. Buenos Aires: Universidad de Belgrano and IUSAM. Research Reports No. 1.

Borensztein, L. 2016. Subjetividad social, una redundancia a cuestionar [Social subjectivity: A redun- dancy to be questioned]. Presentation at scientific conference of Asociación Escuela de Psicoterapia para Graduados (AEAPG) [Psychotherapy School Association for Graduates].

Bucci, W. 1997. Psychoanalysis and Cognitive Science: A Multiple Code Theory. New York: Guilford Press. Bucci, W. 2007. "Building the Research-Practice Interface: Achievements and Unresolved Questions." In From Impression to Inquiry: A Tribute to the Work of Robert Wallerstein, edited by W. Bucci, N. Freedman, and E. Graham, 175-204. London: Karnac.

Bystedt, S., A. Rozental, G. Andersson, J. Boettcher, and P. Carlbring. 2014. "Clinicians' Perspectives on Negative Effects of Psychological Treatments." Cognitive Behaviour Therapy 43 (4): 319-333.

de Maat, S., F. de Jonghe, R. de Kraker, F. Lesichering, A. Abbass, P. Luyten, et al. 2013. "The Current State of the Empirical Evidence for Psychoanalysis: A Meta-Analytic Approach." Harv Rev of Psychiatry 21 (3): 107-137.

Desmet, M., R. Meganck, C. Seybert, J. Willemsen, F. Geerardyn, F. Declercq, Ruth Inslegers, et al. 2013. "Psychoanalytic Single Cases Published in ISI-Ranked Journals: The Construction of an Online Archive." Psychotherapy and Psychosomatics 82: 120-121.

de Souza, L. y Zytner, R. (2016). La Entrevista Clínica y la Formulación Psicodinámica de Caso. En La formulación psicodinámica de caso. Su valor para la práctica clínica. R. Bernardi; B.Varela;D. Miller;

R. Zytner,L. de Souza y R.Oyenard. Montevideo, Uruguay: Grupo Magro.

Etchegoyen, R. H. 1991. The Fundamentals of Psychoanalytic Technique (P. Pitchon, Trans.). Oxford, England: Karnac. [(1986) Los fundamentos de la técnica analítica. Buenos Aires: Amorrortu Editores.].

Fitzpatrick-Hanly, M. A. 2014. Discussion: Further Reflections on the Clinical Narrative of Virginia Ungar, and the use of Anchor Points to Track Transformations. In Time for Change: Tracking Transformations in Psychoanalysis - the Three-Level Model, edited by M. Altmann, 113-121. London: Karnac. [2015. Discusión. Otras reflexiones sobre el material clínico de Virginia Ungar y el uso de los puntos de anclaje para hacer un seguimiento de las transformaciones. In: Altmann M, editor. Tiempo de cambio: indagando las transformaciones en psicoanálisis: el modelo de los tres niveles. London: Karnac.].

Flückiger, C., M. G. Holtforth, H. Jörg Znoj, F. Caspar, and B. E. Wampold. 2013. "Is the Relation between Early Post-Session Reports and Treatment Outcome an Epiphenomenon of Intake Distress and Early Response? A Multi-Predictor Analysis in Outpatient Psychotherapy." Psychotherapy Research 23 (1): 1-13.

Fonagy, P., ed. 2002. An Open Door Review of Outcome Studies in Psychoanalysis. 2nd rev. ed. London: International Psychoanalytical Association. 
Fonagy, P., T. Leigh, H. Steele, R. Kennedy, G. Mattoon, M. Target, and A. Gerber. 1996. "The Relation of Attachment Status, Psychiatric Classification and Response to Psychotherapy." Journal of Consulting and Clinical Psychology 64: 22-31.

Freud, S. 1913. "On Beginning the Treatment (Further Recommendations on the Technique of Psycho-Analysis I)." SE 12: 121-144.

Green, A. 2005. "The Illusion of Common Ground and Mythical Pluralism." The International Journal of Psycho-Analysis 86: 627-632.

Gullestad, S. E. 2014. Close to Observation. Some Reflections on the Value of the ThreeLevel Model for Studying Change. In Time for Change: Tracking Transformations in Psychoanalysis - the Three- Level Model, edited by M. Altmann. London: Karnac. [2015. Aportes a la observación. Algunas reflexiones acerca del valor del modelo de los tres niveles para estudiar los cambios. In: Altmann M, editor, 163-170. Tiempo de cambio: indagando las transformaciones en psicoanálisis: el modelo de los tres niveles. London: Karnac.].

Gunderson, J. G., A. F. Frank, E. F. Ronningstam, S. Wachter, V. J. Lynch, and P. J. Wolf. 1989. "Early Discontinuance of Borderline Patients From Psychotherapy." The Journal of Nervous and Mental Disease 177: 38-42.

Hanly, C. 2014. Foreword. In Time for Change: Tracking Transformations in Psychoanalysis the Three- Level Model, edited by M. Altmann. London: Karnac. [2015. Prefacio. In: Altmann M, editor. Tiempo de cambio: indagando las transformaciones en psicoanálisis: el modelo de los tres niveles. London: Karnac.].

Hanly, C., and M. A. Hanly. 2001. "Critical Realism: Distinguishing the Psychological Subjectivity of the Analyst From Epistemological Subjectivism." Journal of the American Psychoanalytic Association 49: 515-532.

Hannan, C., M. J. Lambert, C. Harmon, S. Lars Nielsen, D. W. Smart, K. Shimokawa, et al. 2005. "A lab Test and Algorithms for Identifying Clients at Risk for Treatment Failure." Journal of Clinical Psychology 61: 155-163.

Hawkins, E., M. Lambert, D. Vermeersch, K. L. Slade, and K. C. Tuttle. 2004. "The Therapeutic Effects of Providing Patient Progress Information to Therapists and Patients." Psychotherapy Research 14 (3): 308-327.

Horwitz, L. 1974. Clinical Prediction in Psychotherapy. New York: Jason Aronson.

Höglend, P., and G. O. Gabbard. 2012. "When is Transference Work Useful in Psychodynamic Psychotherapy? A Review of Empirical Research." In Psychodynamic Psychotherapy Research. Evidence-Based Practice and Practice-Based Evidence, edited by R. A. Levy, J. S. Ablon, and H. Kächele, 449-467. New York: Humana Press.

Jiménez, J. P. 2007. Can Research Influence Clinical Practice? The International Journal of Psycho- Analysis 88(3):661-679. [(2008). ¿Puede la investigación influir la práctica clínica? Revista de la Sociedad Argentina de Psicoanálisis [Journal of the Argentinian Association of Psychoanalysis] 11/ 12:167-191.].

Juan, S. 2014. Inferencias pronósticas e intervenciones en el trastorno de ansiedad generalizada [Prognostic inferences and interventions in generalised anxiety disorder]." ([dissertation]). University of Buenos Aires, Buenos Aires.

Juan, S., and I. Etchebarne, V. Waizmann, A. Leibovich de Duarte, A. Roussos. 2009. El proceso infer- encial clínico, el pronóstico y las intervenciones del psicoterapeuta [The clinical inferential process, prognosis and the psychotherapist's interventions]. Faculty of Psychology, University of Buenos Aires / Department of Research / Yearbook of Research, vol. XVI.

Kantrowitz, J. 2014. Discussion of Paula with 'no History'. In Time for Change: Tracking Transformations in Psychoanalysis - the Three-Level Model, edited by M. Altmann, 237244. London: Karnac. [2015. Discusión. In: Altmann M, editor. Tiempo de cambio: indagando las transformaciones en psicoanálisis: el modelo de los tres niveles. London: Karnac.].

Kächele, H., C. Albani, A. Buchheim, M. Hölzer, R. Hohage, E. Mergenthaler, J. P. Jiménez, et al. 2006. The German Specimen Case, Amalia X: Empirical Studies. The International Journal of Psycho- Analysis 87:809-826. [(2007). Estudios empíricos en la sujeto Amalia X. Clínica e investigación Relacional 1(1):177-191.]. 
Kächele, H., and J. Schachter. 2014. "On Side Effects, Destructive Processes, and Negative Outcomes in Psychoanalytic Therapies: Why is it Difficult for Psychoanalysts to Acknowledge and Address Treatment Failures?" Contemporary Psychoanalysis 50: 233258.

Kächele, H., J. Schachter, H. Thomä, and Ulm Psychoanalytic Process Research Study Group. 2009. From Psychoanalytic Narrative to Empirical Single Case Research. Implications for Psychoanalytic Practice. New York, London: Routledge.

Kächele, H., and H. Thomä. 1995. Investigación del proceso psicoanalítico: métodos y logros. Psicoanálisis APdeBA 19 (1-2):95-117.

Kernberg, O. 1984. Severe Personality Disorders: Psychotherapeutic Strategies. New Haven, London: Yale Univ. Press. [(1987). Trastornos graves de personalidad, p. 1-23. Mexico City: El Manual Moderno.].

Kernberg, O. 1999. "Psychoanalysis, Psychoanalytic Therapy and Supportive Psychotherapy: Contemporary Controversies." The International Journal of Psychoanalysis 80: 1075-1091.

Kernberg, O. 2006. "Identity: Recent Findings and Clinical Implications." The Psychoanalytic Quarterly 75: 969-1004.

Lambert, M. 2007. "Presidential Address: What we Have Learned Form a Decade of Research Aimed at Improving Psychotherapy Outcome in Routine Care." Psychotherapy Research 17 (1): 1-14.

Lambert, M. J., ed. 2013. Bergin and Garfield's Handbook of Psychotherapy and Behavior Change. 6th ed. New Jersey: Wiley.

Lambert, M. J., and B. M. Ogles. 2004. "The Efficacy and Effectiveness of Psychotherapy." In Handbook of Psychotherapy and Behavioral Change, edited by A. Bergin, and S. Garfield, 5th ed., 139-193. New York: J. Wilsey.

Lambert, M., J. Whipple, D. Smart, D. Vermeersch, S. Nielsen, and E. Hawkins. 2001. "The Effects of Providing Therapists with Feedback on Patient Progress During Psychotherapy. Are Outcomes Enhanced?" Psychotherapy Research 11 (1): 49-68.

Lancelle, G. 1997. El psicoanálisis y la investigación en escorzo desde una perspectiva clínica [Psychoanalysis and research in perspective from a clinical point of view]. Psicoanálisis APdeBA [Psychonalysis Journal of the Psychoanalytic Association of Buenos Aires] XIX(1- 2):119-156.

Leibovich de Duarte, A. 1996. Variaciones entre psicoanalistas en el proceso inferencial clínico. Investigaciones en psicología [Variations between psychoanalysts in the clinical inference process: Research in Psychology]. Revista del Instituto de Investigaciones. Facultad de Psicología, UBA [Journal of the Institute of Research, Faculty of Psychology, University of Buenos Aires] 1:27-38.

Leibovich de Duarte, A. 2000. La dimensión ética en la investigación psicológica [The ethical dimen- sion in psychological research]. Revista del Instituto de Investigaciones. Facultad de

Psicología, UBA [Journal of the Institute of Research, Faculty of Psychology, University of

Buenos Aires] 5(1):41-61. Leibovich de Duarte, A. 2006. Going beyond the information given:

Constructing our clinical hypoth- eses [Internet]. Bulletin of the European Psychoanalytic

Federation. Available from: http://www.epf- fep.eu/eng/article/contribution-from-sociedadargentina-de-psicoanalisis-january-2006-going-be yond-the-information-given-constructing-our-clinical-hypotheses.

Leibovich de Duarte, A. 2010. "Psychotherapists at Work. Exploring the Construction of Clinical Inferences." In Personality, Human Development, and Culture. International Perspectives on Psychological Science, edited by R. Schwarzer, and P. Frensch, Vol. 2, 29-43. New York: Psychology Press.

Leibovich de Duarte, A., C. Duhalde, V. Huerín, A. Roussos, M. E. Rubio, G. Rutsztein, et al. 2004. "Theoretical Framework and its Influence on Clinical Practice." 35th international meeting of the society for psychotherapy research, Rome, Italy, 2004 Jun 16-19.

Leibovich de Duarte, A., V. Huerín, A. Roussos, G. Rutsztein, and F. Torricelli. 2002. "Empirical Studies on Clinical Inference: Similarities and Differences in the Clinical Work of Psychotherapists with Different Theoretical Approaches and Levels of Experience." In An Open Door Review of Outcome Studies in Psychoanalysis, edited by P. Fonagy, 2nd rev. ed., 201-204. London: International Psychoanalytic Association. 
Leichsenring, F., and S. Rabung. 2011. "Long-term Psychodynamic Psychotherapy in Complex Mental Disorders: Update of a Meta-Analysis." British Journal of Psychiatry 199: $15-22$.

Leuzinger-Bohleber, M. 2014. Depression and Trauma: The Psychoanalysis of a Patient Suffering From Chronic Depression. In Time for Change: Tracking Transformations in Psychoanalysis - the Three- Level Model, edited by M. Altmann, 122-162. London: Karnac. [2015. La depresión y el trauma: el psicoanálisis de un paciente con depresión crónica: un ejemplo de estudio de caso basado en los tres niveles de observación clínica. In: Altmann M, editor. Tiempo de cambio: indagando las transformaciones en psicoanálisis: el modelo de los tres niveles. London: Karnac.].

Leuzinger-Bohleber, M., and H. Kächele, eds. 2015. An Open Door Review of Outcome and Process Studies in Psychoanalysis. 3rd ed. London: International Psychoanalytical Association.

Levy, K., J. C. Ehrenthal, F. E. Yeomans, and E. Caligor. 2014. "The Efficacy of Psychotherapy: Focus on Psychodynamic Psychotherapy as an Example." Psychodynamic Psychiatry 42 (3): 377-422.

Liberman, D. 1972. Evaluación de las entrevistas diagnósticas previas a la iniciación de los tratamien- tos analíticos [Evaluation of diagnostic interviews prior to initiation of analytic treatments]. Rev Argent Psicoanal [Argentina Journal of Psychoanalysis] 39:461-483.

Lutz, W. 2002. "Patient-focused Psychotherapy Research and Individual Treatment Progress as Scientific Groundwork for an Empirical Based Clinical Practice." Psychotherapy Research 12: 251-272.

Lutz, W., T. Ehrlich, J. Rubel, N. Hallwachs, M. Röttger, C. Jorasz, Sarah Mocanu, et al. 2013. "The ups and Downs of Psychotherapy: Sudden Gains and Sudden Losses Identified with Sessions Reports." Psychotherapy Research 23 (1): 14-24.

Lutz, W., M. J. Lambert, S. C. Harmon, A. Tschitsaz, E. Schürch, and N. Stulz. 2006. "The Probability of Treatment Success, Failure and Duration. What can be Learned From Empirical Data to Support Decision Making in Clinical Practice?" Clinical Psychology \& Psychotherapy 13 (4): 223-232.

Luyten, P., and S. Blatt, J. Corveleyn. 2006. Minding the gap Between Positivism and Hermeneutics in Psychoanalytic Research. J Amer Psychoanal Assn 54 (2):627-632. [Salvando la distancia entre el positi- vismo y la hermenéutica en la investigación psicoanalítica. Hacia modelos integradores. Aperturas Psicoanalíticas [Psychoanalytic Openings] 4. Available from: http://apa.sagepub.com/content/54/2/571. Macdonald, J. 2014. "'Formal' Feedback in

Psychotherapy as Psychoanalytic Technique."

Psychodynamic Practice 20 (2): 154-163.

Maskit, B., W. Bucci, and A. Roussos. 2002. "The Discourse Attributes Analysis Program: Parameters and Problems." 33rd international annual meeting of the society for psychotherapy research, 2002, Santa Barbara, United States.

McLaughlin, J. T. 1991. "Clinical and Theoretical Aspects of Enactment." Journal of the American Psychoanalytic Association 39: 595-614.

McLaughlin, J. T., and M. Johan. 1992. "Enactments in Psychoanalysis." Journal of the American Psychoanalytic Association 40: 827-841.

McWilliams, N. 2011. Psychoanalytic Diagnosis: Understanding Personality Structure in the Clinical Process. 2nd ed. New York: The Guilford Press.

National Law 23,277. 1985. Ley Nacional 23.277 de Ejercicio Profesional de la Psicología [National Law 23,277 on Professional Psychological Practice]. 23.277/85: Reglamentación [Regulation]. Boletín Oficial [Official Gazette] No. 25,806. Section 1, 1985 Dec 12. [Internet]. Available from: http:// psicologos.org.ar/normasyleyes/.

Oddli, H. W., and M. H. Rønnestad. 2012. "How Experienced Therapists Introduce the Technical Aspects in the Initial Alliance Formation: Powerful Decision Makers Supporting Clients' Agency." Psychotherapy Research 22 (2): 176-193.

Olivera, J., M. Braun, M. Gómez Penedo, and A. Roussos. 2013. "A Qualitative Investigation of Former Clients' Perception of Change, Reasons for Consultation, Therapeutic Relationship, and Termination." Psychotherapy 50 (4): 505-516.

OPD Task Force. 2008. Operationalized Psychodynamic Diagnosis OPD-2: Manual of Diagnosis and Treatment Planning. Boston: Hogrefe. [Diagnóstico psicodinámico operacionalizado (OPD-2). Manual para el diagnóstico, indicación y planificación de la psicoterapia. Barcelona: Herder].

PDM Task Force. 2006. Psychodynamic Diagnostic Manual. Silver Spring, MD: Alliance of Psychoanalytic Organizations. 
Persano, H. 2005. Diagnóstico e Indicaciones [Diagnosis and Indications]. Revista de la Sociedad Argentina de Psicoanálisis [Journal of the Argentine Society of Psychoanalysis] 7/8:187-211.

Persano, H. L., A. Ventura, and G. Weisbrot. 2011. Utilidad del diagnóstico psicodinámico estructural en psiquiatría contemporánea: Herencia y futuro [The usefulness of structural psychodynamic diagnosis in contemporary psychiatry: Past and future]. In Association of Argentinian Psychiatrists, editor. Aportes a la psiquiatría argentina del siglo XXI [Contributions to $21^{\text {st }}$ century Argentinian psychiatry], p. 217-222.

Pichon-Rivière, E. 1971. Del psicoanalisis a la psicología social [From psychoanalysis to social psychol- ogy]. Buenos Aires: Editorial Galerna.

Rodríguez Quiroga de Pereira, A., R. Ragau, L. Borensztein, and S. Jadur. 2007. "Authors who Have an Impact on Candidates' Training: Cultural Differences and Theoretical Languages." The International Journal of Psychoanalysis 88 (5): 1245-1261.

Roos, J., and A. Werbart. 2013. "Therapist and Relationship Factors Influencing Dropout From Individual Psychotherapy: A Literature Review." Psychotherapy Research 23 (4): 394-418. doi:10. 1080/10503307.2013.775528.

Roussos, A., L. Boffl Lissin, and A. Leibovich de Duarte. 2007. "The Importance of the Theoretical Framework in the Formulation of Clinical Inferences in Psychotherapy." Psychotherapy Research 17 (5): 535-543.

Roussos, A., and M. Braun, J. Olivera. 2013. Conductas Responsables Para la Investigación en Psicología: Guía Práctica [Responsible conduct for research in psychology: A practical guide]. 1st ed. Buenos Aires: FUNICS.

Roussos, A., and M. O'Connell. 2005. Construcción de un diccionario ponderado en español para medir la Actividad Referencial [Construction of a weighted Spanish dictionary for measuring Referential Activity]. Revista del Instituto de Investigaciones de la Facultad de

Psicología, UBA [Journal of the Faculty of Psychology's Research Institute, University of

Buenos Aires 10:99-119. Roussos, A., and M. Vallejo. 2004. El psicoanálisis y su relación con los modelos de salud mental basados en la evidencia [Psychoanalysis and its relation to evidence-based models of mental health]. Revista de Psicoanálisis [Journal of Psychoanalysis] 61:817-835.

Sandell, R. 2012. "Research on Outcomes of Psychoanalysis and Psychoanalysis-Derived Psychotherapies." In Textbook of Psychoanalysis, edited by G. O. Gabbard, B. E. Litowitz, and W.

H. Kracke, 385-404. Washington, DC: American Psychiatric Press.

Sandler, J. 1983. "Reflections on Some Relations between Psychoanalytic Concepts and Psychoanalytic Practice." The International Journal of Psycho-Analysis 64: $35-45$.

Shedler, J. 2010. "The Efficacy of Psychodynamic Psychotherapy." American Psychologist 65: 98-109. Shedler, J., and D. Westen. 2004a. "Dimensions of Personality Pathology: An

Alternative to the Five-

Factor Model." American Journal of Psychiatry 161: 1743-1754.

Shedler, J., and Westen D. 2004b. "Refining Personality Disorder Diagnoses: Integrating Science and Practice." American Journal of Psychiatry 161: 1-16.

Shedler, J., and Westen D. 2006. "Personality Diagnosis with the Shedler-Westen Assessment Procedure (SWAP): Bridging the Gulf between Science and Practice." In Psychodynamic Diagnostic Manual, edited by PDM Task Force, 1728-1830. Silver Spring, MD: Alliance of Psychoanalytic Organizations.

Shedler, J., and Westen D. 2007. "The Shedler-Westen Assessment Procedure (SWAP): Making Personality Diagnosis Clinically Meaningful." Journal of Personality Assessment 89: 41-55.

Skodol, A., P. Buckley, and E. Charles. 1983. "Is There a Characteristic Pattern to the Treatment History of Clinical Outpatients with Borderline Personality?" The Journal of Nervous and Mental Disease 177: 405-410.

Smith, T., H. Koenigsberg, F. Yeomans, J. Clarkin, and M. Selzer. 1993. Predictors of dropout in psycho- dynamic psychotherapy of borderline personality disorder. Unpublished manuscript. The New York Hospital Cornell Medical Center, Westchester Division, White Plains, N.Y.

Stein, A. 1972. "Causes of Failure in Psychoanalytic Psychotherapy." In Success and Failure in Psychoanalysis and Psychotherapy, edited by B. Wolman, 37-52. New York: The Macmillan Company. 
Stevenson, J., and R. Meares. 1992. "An Outcome Study of Psychotherapy for Patients with Borderline Personality Disorder." American Journal of Psychiatry 149: 358-362.

Thomä, H., and H. Kächele. 1989. The Relationship between Theory and Practice. In

Psychoanalytic Practice: 1 Principles, edited by H. Thomä, and H. Kächele, 353-371. Berlin:

Springer-Verlag.In Thomä H, Kächele H, editors. Teoría y Prácticadel Psicoanálisis 1, 409-

428. Barcelona: Herder S.A. Ungar, V. 2014. Tracking Patient Transformations: The Function of Observation in Psychoanalysis. In Time for Change: Tracking Transformations in Psychoanalysis - the Three-Level Model, edited by M. Altmann, 97-121. London: Karnac. [2015. El seguimiento de transformaciones de pacientes. La función de observación en psicoanálisis. In: Altmann M, editor. Tiempo de cambio: indagando las transformaciones en psicoanálisis: el modelo de los tres niveles. London: Karnac.].

Waldinger, R. J., and J. G. Gunderson. 1987. Effective Psychotherapy with Borderline Patients. Case Studies. New York: Macmillan.

Wallerstein, R. 1988. "One Psychoanalysis or Many?" The International Journal of PsychoAnalysis 69: 5-21.

Wallerstein, R. 2005a. "Dialogue or Illusion? How do we go from Here? Response to André Green." The International Journal of Psychoanalysis 86: 633-638.

Wallerstein, R. 2005b. "Will Psychoanalytic Pluralism be an Enduring State of our Discipline?" The International Journal of Psychoanalysis 86: 623-626.

Wallerstein, R. 2006. "The Relevance of Freud's Psychoanalysis in the 21st Century: Its Science and its Research." Psychoanalytic Psychology 23 (2): 302-326. Available from: http://doi.org/10.1037/0736- 9735.23.2.302.

Weber, J. J., H. M. Bachrach, and M. Solomon. 1985. "Factors Associated with the Outcome of Psychoanalysis. Report of the Columbia Psychoanalytic Center Research Project (II)." International Revue of Psychoanalysis 12: 127-141.

Zukerfeld, R. 2014. El aguante, la humillación y las herramientas: a propósito del caso Elsa [Endurance, humiliation and tools: On the Elsa case]. Siglo XXI: herramientas y dispositivos del psicoanálisis [21st century: Tools and devices in psychoanalysis]. Annual Symposium of the Buenos Aires Psychoanalytic Association, 94-100. Oct 30-Nov 1, Buenos Aires, Argentina.

Zysman, S., and A. Segura Villa, L. Bordone de Semeniuk, A. Pieczanski. 2009. Las teorías en la mente del analista durante su trabajo [Theories in the mind of the analyst at work]. Psicoanálisis [Psychoanalysis] 31 (1):203-216. 